\title{
THE REVIVAL OF SPIRITISM
}

\author{
PSYCHCLOGIC FACTORS* \\ C. B. FARRAR, M.D.
}

Chief Psychiatrist, Department of Soldiers' Civil Reestablishment

OTTAWA, CANADA

The only method known to science of extracting information from deceased persons is the discovery of documents.-Sir Oliver Lodge.

The reconstruction periods following devastating wars are axiomatically characterized by widespread nervous unrest. The causes and effects of this universal state of "nerves" are too familiar to require mention. One of the most readily understood accompaniments of such a period of readjustment is a recrudescence of all kinds of religious activity and of divers affiliated undertakings.

Of these phenomena perhaps the most striking, because of certain personages involved, is the contemporary wave of spiritism.

In the western world this wave, which has taken form in the spectacular missionary tour of England's foremost spirit-scientist, has flowed across the states from East to West, and is now receding through the provinces from West to East. It promises temporary interest or enthusiasm, to be followed by forgetfulness, awaiting the impetus of a later wave.

Were we to inquire into the earliest antecedents of this movement, we should have to go back to the witches of the Old Testament and the oracles of Greece. Early Greek and Roman writers, from the sixth century B. C. onward, have left descriptions of mysterious happenings among which the modern student of ghost lore would have been entirely at home. The wonderful performances of the twentieth century medium, like many another pseudo-novum, had their prototype and pattern in the early days of our race.

\section{ORIGIN OF MODERN SPIRITISM}

But it is not with this ancient story that we are here concerned. Modern spiritism dates from 1848. It had its origin in the humble village of Hydesville, near Rochester, N. Y., in the home of a family named Fox. It may not be impertinent here to suggest parenthetically that as it is one of the avowed functions of the Society for Psychical Research to investigate striking coincidences, the circumstance that this

* Read at the first meeting of the Ontario Neuropsychiatric Association, Kingston, April 28, 1920. 
particular family should have borne the name of "Fox" may be worthy of some speculation. Be this as it may, the fact remains that the two Fox sisters, aged 15 and 12 when they began their careers, were the founders of the contemporary school of mediumship.

As the starting point of the modern epoch in the history of credulity, the Hydesville episode merits a few moments' attention. The Fox family, migrating from Rochester to Hydesville, had taken quarters in a house described by a writer of the time as "quiet and respectable, for aught that is stated, and there is no reason to suppose that the timber had been practiced on by elves or the 'good people' who haunt the woods." Shortly after establishing themselves in this house, "they were disturbed after going to bed by various noises-which, however, did not attract much attention, as they supposed them to be made by the rats which do sometimes of themselves have strange doings." At length, after about four months of these experiences, the family one night "determined to go to bed early, so as to get a good night's rest, in spite of all noise, but this was not permitted; the thought then struck Mrs. Fox, whose bed was in the same room with that of her two daughters, that she would question the noise.

"Who makes the noise?" (Silence).

"Is it made by any person living?" (Silence).

"Is it made by one dead?" (Rap).

"By an injured spirit?" (Rap).

"Injured by me or my family?" (Silence).

At this point it was deemed safe and wise to convoke the family and such neighbors as might conveniently be brought to the scene. Further questioning as to the date of the supposed injury, elicited five raps; and when various names were mentioned, there was an accusing rap at the name of a man who had occupied the house about five years previously. Pursuing the interrogation, they were given to understand by affirmative raps that the body of the injured spirit was buried in the cellar and might there be found. They were admonished, however, not to dig for a space of four months. It is recorded that when this period had elapsed some fragments of bone were disinterred in the cellar; but it does not appear to have been ascertained to what animal they belonged, or how long they had lain in the earth.

It will readily be understood that there was no little commotion in Hydesville; and it was not long before the Fox family found it advantageous to leave not only the house, but the village, "as the excitement for or against them was so considerable." The noteworthy circumstance was that in the journeyings of the family, wherever either of the daughters happened to be staying, there the mysterious sounds infallibly occurred; and in due time certain relatives or friends who 
had enjoyed association with them likewise developed mediumistic talents.

Within two or three years a veritable spirit epidemic had spread through New York and adjoining states, east, west and south. Séances were the order of the day, or rather of the night; and all the technic and lingo which one may find in any present day textbook of spiritism were fully developed in that middle nineteenth century outbreak. Bereaved parents held converse with their spirit children in dialogues almost identical with those reported in "Raymond" between Sir Oliver Lodge and his departed son; ponderous objects acquired automotive qualities; under spirit influence the force of gravity was set at naught, or intensified a hundred fold, just as Mr. Crawford finds today in Ireland; currents of air, breezes from the beyond, fanned the faces of the faithful; impressive materializations took place; indeed the "direct voice" of the spirit was occasionally heard; nor were there wanting tokens of affection which under cover of darkness were discreetly bestowed on expectant sitters just as in the modern séance room.

The departed great "came through" in high-sounding platitudes, and the foundation principles of nature afterward were enunciated in language singularly out of keeping with the earthly history of the alleged communicants. In the old days, as today, the spirits of mischief were conspicuous and active, and there is ample documentary evidence set forth in the early fifties of the mad pranks of the Poltergeist, not only making night hideous but also involving the general dislocation of households and the destruction of property.

Let it be added that in those pre-Society-for-Psychical-Research days the religious factor soon came to be the driving force in the circles of the devotees; death had lost its sting, the grave its victory; the substance of things hoped for had gloriously become the sure evidence of things seen, heard and even handled; the very words which Sir Arthur Conan Doyle has used for a title to a recent book, "The New Revelation," were employed to denote the "new" gospel of 1850, which then just as now-although in the interim the fact seems to have been unaccountably forgotten - was destined to tower above and supersede all other forms of religion.

But we must not delay longer over this story of seventy years ago. It is only necessary to say that all minds were not equally credulous. Even in the early stages of the rappings in the Fox family, there were, as a contemporary critic remarks, ill-disposed and unbelieving people who faintly suggested the daughters as the cause, in spite of their protest of innocence. Eventually their exposure was complete. One investigator concludes his report, which reminds one of the inquiries of the Seibert Commission carried on a few years ago under the auspices of the University of Pennsylvania, with these words: 
In conclusion, let me say, that according to my judgment, nothing of praeternatural or supernatural character took place; and that I was very strongly impressed with the conviction that the three women (Mrs. Fox and her two daughters) were shallow and simple cheats and tricksters, who, perhaps from an accident, had been led on by credulous people to impose upon them.

The Fox episode and its ending are worth bearing in mind because of the fact that notwithstanding the cheapness of their methods and the facility with which they were uncovered, one of the great exponents of the cult in our own day, no less a man than Conan Doyle, harks back to the Fox family as the legitimate sponsors of the new religion which is to regenerate the world. Sir Arthur uses these somewhat astonishing words:

The lowly manifestations of Hydesville have ripened into results which have engaged the finest group of intellects in this country during the last twenty years; and they are destined, in my opinion, to bring about by far the greatest development of human experience which the world has even seen.

\section{ASPECTS OF SPIRITISM}

The modern spiritistic period has been marked by three great waves: the inaugural midcentury wave I have just been discussing, the present postbellum flux, and midway between these the wave which followed the organization of the Society for Psychical Research.

In practice the traffic in spirits has taken on various aspects during this period. It has served as a mode of entertainment. Spiritistic performances have been put on for popular amusement as favorite parlor games. Heavy tables have acquired terpsichorean agility ; blindfolded people have been constrained through "telepathy" to execute the will of the sitters; the ouija board has been brought into requisition as a faith-tinged pastime or sentimental diversion. On a larger scale, traveling showmen, with all the paraphernalia of the séance room, have staged exhibitions to delight the million. Such performers have outdone the Witch of Endor in their materializing accomplishments. The most remarkable of these shows in its time, perhaps for all time, was that of the clever handcuff kings, the Davenport brothers, who finally came to grief in their exhibition at Ithaca, N. Y., where some Cornell students made their way unobserved in the darkened room to the edge of the stage, and by turning on several strong flash-lights revealed the modus operandi of the mystical brothers to the satisfaction of all save those perchance who hunger and thirst after deception.

Second, the traffic in spirits has become an organized commercial undertaking. In addition to the itinerants whose business, like that of other conjurers, is to furnish a good show at a stipulated entrance fee, there are multitudes of settled mediums located in practically all the larger towns and cities who make their irregular living out of human credulity and gullibility. It is said that these imposters have a more or 
less complete nation-wide organization, with central clearing houses for "spirit information" and elaborate lists of dupes in fact or prospect. This spirit trust has been discussed with considerable documentation by Edward H. Smith in the Saturday Evening Post of April 24, 1920.

Third, spiritism has become a country cousin of science. This phase of the movement stands to the "credit" of England where, in 1882, was formed the Society for Psychical Research. A similar organization sprang up in the United States in 1884. In this society were enrolled men prominent in science, literature and the professions. Records of unusual manifestations of all sorts were brought together; spiritistic experiments were conducted under "test" conditions which the experimenters considered satisfactory from the scientific point of view. The sincerity of the leaders of this movement is not to be questioned; and an enormous mass of curious literature represents the fruit of their labor and researches.

Finally, spiritism has become a new religion. This is the logical culmination of the spiritistic movement, as in fact the religious feature has always been the essential one whether recognized or not. Spirit circles have generally adopted the commoner religious rites and ceremonies; and as an intruder in the field of religion spiritism has ever aroused the antagonism of the churches, jealous of their own authority and methods. But now notwithstanding, in the aftermath of the world war, the formal attempt is being made to organize this great body of new-old doctrine into a new religious system. In the opinion of Conan Doyle: "No other religious movement in the world could put forward anything to compare with it." In his "New Revelation" this author vouchsafes to inquiring humanity a description of the life beyond which rivals in details that of St. John, the Divine; but it differs considerably from the latter, and, it may be added, is a trifle more in conformity. with what may be taken to be present-day human aspirations.

\section{CONTEMPORARY SPIRITISM AS A RELIGIOUS MOVEMENT}

In dealing with the subject of contemporary spiritism, therefore, we must consider it as essentially a religious movement. As a religious development spiritism has followed traditional ways. In the history of religion magic was ever the starting point. In establishing communication between the devotee and the Deity magic rites, presided over by the head of the tribe, were the means resorted to, and were believed to have the virtue of controlling the operations of nature and compelling the favor of the Deity. As religious systems grow and mature along with the cultural progress of the race, magic rites tend to recede into the background, although they have never disappeared completely. 
Numerous familiar forms and ceremonies in the church today are plainly reminiscent of the incantations of a cruder age.

The ordinary professional spiritistic séance is a very good replica of the magic rites of primitive society. Indeed the whole spiritistic movement is flagrantly atavistic and reflects the animism of the childhood of the race. Tylor remarked that the "spiritualistic theory belongs to the philosophy of the savages."

We have, then, as a starting point the two-fold fact: Spiritism is a religion; and it is a reflection of the religion of the most primitive stages of human society. This circumstance, that the subject is a religious one, hampers discussion somewhat, and has a peculiar effect on the attitude of the individual. There are certain subjects concerning which the majority of people have a curious mental bias which makes them more or less inaccessible to foreign and conflicting opinions. Among such subjects religion stands conspicuously foremost. Persons of diverging views on religion can rarely be brought to agree. The same may be true of politics, although to a lesser degree; while in the field of science this personal bent or bias is supposed to manifest itself least of all, the standpoint of the individual being determined by objective facts.

This peculiarity and the difficulty attached to the discussion of religious questions may be explained on the basis of the following considerations:

Religion in its highest reaches is essentially an expression or an outgrowth of the affective state of the individual. It is based on feeling rather than judgment, and the function of religion is to serve the most intimate personal needs of the devotee. In his classical treatise on the "Varieties of Religious Experience," Professor James uses these words: "The pivot round which the religious life, as we have traced it, revolves, is the interest of the individual in his private personal destiny. Religion in short is a monumental chapter in the history of human egotism."

Because of these two features, the dominant affective element and its identification with the vital self-interest of the individual, his religious belief may be said to be more a part of himself than any other it $\epsilon \mathrm{m}$ in his mental equipment. That it should be beyond the influence of attack or criticism follows naturally enough. These considerations are pertinent in the discussion of spiritism as in any other form of religion.

But just as the majority of people are not absorbingly religious, so the number of spiritists, although now declared to be increasing remarkably, is still relatively small in the total population. The question - What determines a man's deviation toward spiritism? - is only another form of the question - Why is one man more religious than 
another? The matter of temperament here demands consideration. It is not too much to say that a person's temperament determines in general what his religious attitude will be. This fact was clearly set forth in Sir William Osler's splendid essay "Science and Immortality." You recall that he divided mankind into three classes: (1) the small band of devoted Teresians living strictly the religious life, willing to die for their belief if need be; $(2)$ at the opposite pole the skeptical or disbelieving Gallionians; (3) while intermediate between the two and making up the bulk of humanity are the indifferent or neutral Laodiceans, who may lean perhaps one way or the other, according to circumstances, but who never go to the extreme of blind faith or agnostic scoffing, and remain more or less undisturbed and unaffected by the zealous activities of their neighbors on either side.

It is well to recognize, therefore, that personal attitudes typified by these three classes are not arrived at by processes of deliberation, logic and judgment, but are first and last questions of temperament, to change which lies not within the power of the individual. While the Laodicean may conceivably vere toward the point of view of the Gallionian or the Teresian, that either of the latter should be transformed would be almost miraculous, if not pathologic. "Let him that is scornful be scornful still" were words which had a deeper meaning than is usually supposed.

\section{BELIEF IN SPIRITS BASED ON TEMPERAMENT}

The theory of temperaments until lately had fallen somewhat into neglect in scientific circles, but is again coming into its own. Personality and character studies have led to the contemporary teaching of the individual constitution which is a definite and unchanging affair. It represents the hereditary and developmental neuropsychic attitudes, tendencies, and inclinations - the mental sets of the individual which determine the way of his whole life and which he cannot escape.

This tyranny of our constitutional bents or mental tropisms must ever be borne in mind in considering a subject like the present one; and it must be further remembered that the constitutional trends with which we start early in life become fixed and reinforced as we go along, so that in our middle or later years we may be no more able to think or act out of harmony with them than to break through the steel bars of a prison.

Osler's categories apply equally to spiritism. Looking at the subject in this way it seems fair to conclude that the belief in spirits is not in the last analysis, as believers often take pains to tell us, an acquired belief quite foreign to their former mental habits and based solely on "evidence." Rather I think the belief in spirits is an act in faith temperamentally determined. 
The biographies of some of the most noted modern spiritists throw light on this view. It is a matter of fact that all the best known exponents of this system of occultism have practically devoted their lives to the subject. Meyers, Hodgson, Barrett, Lodge, Doyle, all have spent many years in the spirit land. It is well to insist on this point, the significance of which is perhaps not sufficiently appreciated. Assuming the natural constitutional bent, these men having dedicated themselves to the inquiry, grew old in their quest, which assuming for them more and more importance as the years passed, eventually became a veritable obsession.

Quite naturally the leaders in spiritism look on the steps in their career simply as the gradual piling up of evidence which in the end forces conviction. They all emphasize this view of the matter. They take pains to refer to their earlier skeptical attitude, and to point out that they have not arrived at their conclusion prematurely. Being at length compelled to yield to the, to them, overwhelming mass of "evidence," they are at a loss to understand how any unbeliever reading their reports of this "evidence" can escape sharing their belief. But a consideration of the psychology of conviction is calculated to set the matter in a somewhat different light. Concerning his beginnings, Sir William Barrett in "The Threshold of the Unseen" says, "upwards of forty years ago I began the investigation of alleged supernormal phenomena with a perfectly detached and open mind." Referring to Dr. Hodgson, Sir Oliver Lodge remarks, "He devoted years of his life to the subject and made it practically his whole occupation." Conan Doyle in his "New Revelation" declares, "The subject of psychical research is one upon which I have thought more and about which I have been slower to form my opinion, than upon any other subject whatever." To some persons this may be a surprise. Those of us who have known Sir Arthur only as a physician and as the creator of remarkable characters in fiction are perhaps shocked to find that his type of mind should lend itself so readily to a spirit cult.

Hyslop speaks of the "conversion" of Doyle as a recent event which is calculated to help on the cause wonderfully. This view of Conan Doyle's position is obviously erroneous. In the book just referred to he shows that for more than thirty years he has devoted most of his spare time to psychical research; altholigh "it is only within the last year or two that I have finally declared myself to be satisfied with the evidence." According to his own statement, therefore, the subject of spirit manifestation has been in the other's mind more than "any other subject whatever" for upward of a generation.

Conan Doyle indicates some of the steps by which he has arrived at his present position, and it is interesting to follow these. He finished 
his medical education in 1882, "like many young medical men a convinced materialist as regards our personal destiny." He declares, however, that he was always "an earnest theist" (personal bent). At first he regarded the phenomena of spiritism as "the greatest nonsense upon earth." But he was thrown with friends who were seriously interested in the matter and whose integrity he could not doubt. His inclination also led him to read all the available literature on the subject. He was "amazed to find what a number of great men thoroughly believed that spirit was independent of matter and could survive it." Even at this early time when he was beginning his medical practice he was much more impressed by the attitude of Crookes, Wallace and Flammarion, who believed, than by Darwin, Huxley, Tindall and Herbert Spencer, who disbelieved. In this early choice what else can we see than an expression of the inherent tendencies of the individual mind which, adequately considered, might have foreshadowed to the psychologic observer the denouement thirty years later which Hyslop speaks of as the "conversion" of Conan Doyle?

The author attended some spirit séances at which tab'es were juggled about by unseen forces. Being convinced of the sincerity of the participants and unable to explain the phenomena, he declared himself "puzzled and worried." About this time he read "with interest and absolute skepticism" a book called the "Reminiscences of Judge Edmunds" wherein the judge told of his communications through many years, with his dead wife. Of his early séances Sir Arthur preserved notes. "I was still skeptical, but at least I was an inquirer." Moreover, the time that was not actually used for experiments was devoted to reading psychic literature. This reading, he says, "was continuous." The author had now arrived a little further along his predestined way. He had taken part in the reception of numerous spirit messages, some of which were trivial and irrelevant, while others appeared to carry the stamp of genuineness. He states that while he had no proof of their authenticity "they simply left me bewildered." The cumulative effect of the testimony of others began to make itself felt. The agreement of witnesses he felt constituted "some argument for their truth." He came to "appreciate more and more what a cloud of witnesses existed." It is needless to remark that the author's perspective was possibly not calculated to give him a just idea of the dimensions of this "cloud." As Professor Jastrow has remarked: "The obvious fact is strangely ignored that, for one exceptional scientist who subscribes to the reality of such communication, there are hundreds of equal authority who would violently resent the implication that they might be tempted to draw conclusions as to the nature of the universe from the testimony of mediums trafficking upon human credulity." 
About 1891 Doyle joined the Psychical Research Society and had the "advantage" of reading all their reports, certainly no inconsiderable accomplishment. It does not seem possible that an investigator would have the patience to labor through this vast accumulation of literature if he were entirely dispassionate and not rather striving, however faintly, toward conviction. This state of mind the author had now reached. The influence of the society, he states, "was one of the powers which now helped me to shape my thoughts."

Sir Arthur was helped on a good way toward conviction by reading Meyers' "Human Personality." The thing which impressed him was the testimony concerning telepathy which he found himself ready to admit as an established scientific fact, in spite of dissenting views of the majority of scientific men. The acceptance of telepathy was a red letter day in Doyle's ghost-land travels. "The ground was cut from under the feet of the materialist and my old position had been destroyed." Having arrived thus far, one does not need to wonder that the few remaining steps were easy, nay inevitable. Starting with telepathy at one end of the series of psychic manifestations, the author found an unbroken chain of phenomena culminating in "actual manifestations of the spirit independently of the body."

\section{MENTAL METAMORPHOSIS OF THE SPIRITIST}

Given the necessary temperamental set, any subject which is strongly tinged affectively is likely to get itself so anchored in the subcellars of the mind as to be pursued to the same obsessional length as the spirit quest. Familiar examples are common enough in these days, to mention only certain types of prohibition apostles and vice crusaders, professional reformers, uplifters and self-appointed moral censors of various kinds, ultra-freudologists and antivivisectionists, Christian scientists, feminist extremists, pacifists and red socialists. Such men do not pursue their idea for a time as a fad or diversion and then change it for some other interest; on the contrary, their obsessing idea tends to become a life engrossment, reinforced with the passing years, and from its final utter domination we are probably safe in saying they could not free themselves if they would.

The career of Conan Doyle, as he has himself outlined it, is fairly illustrative of such a gradual mental metamorphosis. Over against his declaration, already quoted, that he had given more thought to psychical research than to any other subject whatever throughout his life, let us set the remark of another eminent scientist to illustrate this question of temperament we are discussing, which determines personal inclinations and attitudes, and which, with respect to any given theory, may make it at the same time impossible for the one mind to accept 
and for the other to reject. The remark was made by Huxley in a discussion with Wallace on the topic of spiritism: "It may all be true for anything I know to the contrary, but really I cannot get up any interest in the subject."

To establish the underlying factors of faith we must study the personality of the believers rather than the reasons they bring forward in defense of their belief. It would be profitable to make such comparative personality studies of a group of religious devotees and a group of chronic skeptics. It is possible that their differential psychology might be found to be largely a matter of endocrine glands, smooth muscle fibers and the autonomic nervous system; and their mutual antipathies rather deducible from physiologic than logical factors.

But there is another feature which has been touched on but to which more specific reference must be made. This is the factor of habit. Sir Arthur repeatedly refers to his continued experiments and his continued reading along the chosen lines. He explains that it was his "interest" which kept him at it. This is, of course, true. We think and ponder over the thing we are interested in and continue to do so for the same reason. However, this continuance establishes a mental process which becomes, as we say, habitual, and which we know tends to be self-perpetuating even were the interest factor to diminsh. In the case before us, however, interest and the habit tendency obviously work together and strengthen each other. After some years of this sort of thing the course of the mental operations of the individual is irretrievably fixed, and in nine cases out of ten he will follow his natural bent thus established to the end of the chapter.

Let us consider still another factor in the psychologic metamorphosis of conviction, namely, the striving, if one may so express it, of every thought process to arrive at a definite goal. Suspended judgment is a painful state; doubt and uncertainty are unpleasant at best and may become intolerable. It seems likely that in certain forms of mental disease definite relief is experienced when anxious uncertainty has been replaced in the patient's mind by the delusional interpretation on the basis of which he can again, after a fashion, adapt himself to his surroundings.

In the nature of things, religious and kindred doubts are the most painful of all. As far as the phenomena of spiritism are concerned, experience shows that inquirers after suspending judgment for a time during which they retain more or less the capacity for dispassionate critique - the skeptical stage, they usually call it - will generally one day end by accepting unreservedly the conclusions toward which their ideas have all along been tending.

The final stage in the mental transformation of the spiritist is that in which he reaches conviction, complete and unassailable, when he 
passes from the stage of so-called scientific inquiry to that of absolute faith. This stage may be attained gradually and naturally without any special accelerating event. The affective coloring of the religious motive with its deep personal concern may be sufficient to usher the individual through the various stages until he has reached the final phase of spiritual calm, self satisfied in his clairvoyance of things past and to come.

For some, however, it may be that a special added motive is needed. The war has furnished this motive. For many the bereavement has been almost intolerable, the loss has seemed so unnatural, so cruel and useless. Both Sir Oliver Lodge and Conan Doyle lost a son in the war. In view of their previous history of spirit seeking, what more natural than that the pursuit should now be continued with redoubled zeal and devotion? That the power of self criticism under such circumstances may become very feeble, it is needless to say. The recent activities of both of these men, the inauguration of a new religion by Doyle and the publication of "Raymond" by Sir Oliver Lodge followed by his missionary trip to North America, are the logical sequels of their previous mental careers under the influence of the World War with its bereavements.

CRITERIA OF EVIDENCE ACCEPTED BY PSYCHIC WORKERS

That in the final religious phase of the gradual psychic metamorphosis we have been outlining the power of criticism is very weak indeed is evidenced by the fact that the exposure of fraud has little or no effect on the faith of the devotee. Thus, after the cheap trickery of the notorious Eusapia Palladino had been brought to light and she herself had been discredited, and although, as Hyslop admits, 300 members of the Society for Psychical Research deserted the spirit camp following these events, Sir Oliver could still say, "I am, therefore, in hopes that the present decadent state of the Neapolitan woman may be only temporary, and that hereafter some competent and thoroughly prepared witness may yet bring testimony to the continued existence of a genuine abnormal power in her organism." Can such a sentiment as this express anything else than a downright headlong will to believe in spite of everything?

Sir Oliver describes another incident which might have shaken the faith of any not unwilling to be undeceived. F. H. W. Meyers had written a message which he had delivered in a sealed envelope to Sir Oliver, to be used as a test after the writer's death. Shortly after this event the message was subjected to mediumistic influence, but not until fourteen years had elapsed was the time deemed ripe to make trial whether the contents of the sealed envelope had been telepathically discerned. The result was complete failure. A sealed message written 
with similar intent by Richard Hodgson is in existence, and a reward of $\$ 1,000$ has been offered to any medium who can reveal it. The reward remains unclaimed.

The quality of the faculty of criticism when under the coercion of faith is further illustrated by the acceptance of the alleged messages from Meyers by Sir Oliver as genuine, although the former was unable during fourteen years following his death to infuse into the mind of any medium the contents of the sealed message which he had expressly prepared for that purpose, and in face of the testimony of Meyers' widow on the subject of these messages, in which she declared, "after a very careful study of all the messages we have found nothing which we can consider of the smallest evidential value."

Reference might here be made to the findings of that indefatigable promoter of things psychic, Mr. Hereward Carrington, in his compilation "The Physical Phenomena of Spiritualism." This authority essays to distinguish "fraudulent" from "genuine" phenomena. In a text of 417 pages he finds it necessary to devote 318 to the former. Those who regret that Mr. Carrington's "genuine" phenomena were only sufficient to fill one fourth of his book, are doomed to further disappointment when they come to this statement (p. 336): "There may be much fraud in modern spiritualism, in fact, I am disposed to believe that fully 98 per cent. of the phenomena, both mental and physical, are fraudulently produced, but," etc.

The disappointment of the reader seeking light in this volume will be grievously supplemented by bewilderment when he discovers that the difference between the "fraudulent" and "genuine" manifestations, for aught that is revealed in the text, lies secluded in the psychic eye of the author. The same kinds of "tests" are described in both sections of the book, the distinction being that the author believes in the one group and disbelieves the other. Moreover, in the "fraudulent" section there are pages devoted to the trick methods by which similar phenomena recorded in the "genuine" section can be produced.

Finally the seeker's disappointment and bewilderment will merge in confused despair when he realizes that the "genuine" matter is made up all but entirely of a series of quotations. Why should these devoted researchers be able to develop no manifestations of their very own? Hidden away in the mass of this book are two pages in which Mr. Carrington records the sum of his personal psychic experiences. These consisted in certain rappings heard in his room at night at about 10 or 11 o'clock and continued until he went to sleep. These noises, which he avers did not sound like creaks, recurred during four or five weeks; one night he located them on his mantel piece, and laying his hand thereon, felt distinctly the vibration of the wond. Therefore $\mathrm{Mr}$. 
Carrington believes in raps. He admits, however, that he could get no intelligence from them. Also, he has sat by the hour over the planchette, but without result. At length one night, at 11 o'clock, his eyes being too tired to permit him to work, he again resorted to the mystic apparatus. By 2 a. $\mathrm{m}$. he had obtained "a few vague scratches." As he was about to give up in disgust there came on the planchette board a few faint raps; then again continued silence. Verily the progeny of the laboring mountains should not after all have been regarded so contemptuously.

Were it desirable to examine further the criteria of evidence which satisfy the psychic researcher, we might cite almost at random the spoken and written words of the author of "Raymond." In an earlier work, "The Survival of Man," Sir Oliver gives his qualifications as an authority on spirit manifestations. "A physicist," he declares, "can make no assertion on it one way or the other. . . . As a physicist I do not know; these are not processes I understand." But spirit information being of a different brand must needs come by other channels than those by which all the rest of our experiential data are acquired; and where faith enters in the censor, logic, nods. Sir Oliver accepts telepathy, but not by the methods of demonstration or the processes of reasoning by which he accepts the facts of science. Such rigid criteria he gives over entirely. He has experimented with telepathy but states that he has not been able personally to demonstrate it. As a "percipient" he failed. For example, when the "five of diamonds" was telepathed to him he got "scissors." As "agent" he likewise failed in the majority of cases. He has known of happenings, however, of which, to the neglect of the law of parsimony, telepathy has seemed to him the sole explanation; and for proof and reason he can only say: "to the best of my scientific belief no collusion or trickery was possible." He had expressed similar belief in Eusapia Palladino.

Let me add a single quotation from "The Survival of Man" (p. 321), which most strikingly exemplifies the polar divergence between the method of arriving at scientific conclusions and that of reaching spiritistic conviction.

The old series of sittings with Mrs. Piper convinced me of survival, for reasons which $I$ should find it hard to formulate in any strict fashion, but that was their distinct effect. They also made me suspect-or more than suspect - that surviving intelligences were in some cases consciously communicatingyes, in some few cases, consciously; though more usually the messages came in all probability from an unconscious stratum, being received by the medium in an inspirational manner analogous to psychometry.

Would one suspect that the foregoing sentence had been written by a scientist? 
A certain characteristic religious intolerance also begins to make its appearance in the writings of this author. In "Raymond" he refers to the "little systems" and "contemporary blindness" of those who do not subscribe to his hypothesis; he speaks of the "assumptions and blind guesses" of men of the materialistic school, and adds this further vocal boomerang, "their device being to anticipate and speak of what they hope for, as if it were already an accomplished fact."

Professor Jastrow, commenting on the type of mind revealed in these various quotations, says:

The phenomenon is a puzzling one; for we associate with the effect of a professional training a general robustness of logical vigor, a thorough saturation of the mind in all its vocations with the habits of rigid evidence and critical caution. We assume a consistency of mental habit, and in that assumption seemingly go astray. We must make room for the existence of minds streaked with rationality but not uniformly penetrated by the stabilizing quality; we must consider reserved areas of prejudice and predilection in which ideas flourish and convictions are cherished with slight regard to their reconciliation with the dominant logicality of the rest of one's beliefs.

But enough has been said to indicate quite clearly that in dealing with the spiritistic theory, we have to do in the main with matters of faith and religious aspiration rather than with the processes of dispassionate scientific inquiry. Indeed the religious climax of the spirit quest following the world war is clearly expressed by Sir Oliver. "For many years I held my tongue but I have come out since the war more into the open because of the extensive bereavement which could be comforted." Here we see the ultimate end of all religious systems, to bring spiritual consolation and assurance which shall satisfy the personal longing and self seeking out of which all religious systems develop.

Conan Doyle similarly describes the effect of the war in his own case. Had it not been for this cataclysm, he says, he might have "drifted on for my whole life simply as a psychic researcher." But in the midst of the agony of war bereavement, "I seemed suddenly to see that this subject with which I had so long dallied was not merely a study of a force outside the realms of science, but that it was really something tremendous, a breaking-down of the walls between two worlds, a direct undeniable message from beyond, a call of hope and of guidance to the human race at the time of its deepest affliction." This language might fit beautifully into an impassioned religious exhortation but it has nothing to do with the calm consideration of scientific facts. The author is no longer an inquirer but a believer. The labor of investigation is over. The voyage is done and the believer is safe in the harbor of his spiritual revelations. As the author expresses it, "the objective side of it ceased to interest, for having made up one's mind that it was true, there was an end of the matter. The religious side of it was clearly of infinitely greater importance." 
The age factor has only indirectly been referred to. This must also be taken into account. No explanation of the fact that religious reflections and practices tend to increase with advancing years is necessary; not only do latent tendencies grow active, but there may take place what at first glance appears to be a constitutional transformation, in that a strikingly irreligious youth is succeeded by a devout old age, bitterly repentant of the "errors" of earlier life. These epochal changes are common enough and will be found not to controvert the idea of temperaments and mental sets which we have been developing. These circumstances may not be of major importance in the present question, but what is of importance is the fact that habitual mental reactions tend to become unalterably fixed in later life, due not only to the habit factor itself in its anatomic and physiologic bearing, but pari passu to the loss of psychic resiliency in old age with its intolerance of the unaccustomed. It is doubtful if the old man, or any of us who are getting on, appreciates what a slave he is becoming to his habitual tendencies in thought and conduct. For the person who has grown old in a religious belief, spiritistic or otherwise, true or false, there is probably no mutation possible.

\section{SUM MARY}

We have come to the final step of our inquiry. We have seen that the leaders of the spiritist movement are men of a certain disposition of mind which predisposes them to this pursuit, which they follow with devoted and increasing interest throughout their lives. The motive of this interest is religious craving, the seeds of which are sown in every breast. For some the age-worn forms of orthodox religion are unsatisfying, and a pseudo-scientific garnish like that of psychical research supplies the necessary appeal. The mental metamorphosis of the spiritist is not difficult to trace. He feels himself at first a skeptic, then a curious onlooker, then an interested inquirer, then an earnest seeker; and finally by this declension a devout believer. If he is called on to describe the process he declares that he has approached the subject with an open mind, and that steadily accumulating "evidence" has at length inevitably forced conviction on him without any motion of his own. What he will not tell you is that having a personal bent for the occult or the shady side of science, the demands of his nature have forced him to devote time and attention in increasing measure to these matters; that the driving force of ultimate personal need has caused him to discern evidence where another might have found only accident, coinicidence, or utter irrelevancy; and that under the enslaving influence of habit crystallized by the passing years, what began as a more or less dispassionate inquiry has ended as a veritable spiritual quest, pressing onward even to the threshold of the abnormal. 
Are the celebrated men who lead the spiritist movement justified in their public attitude and propaganda? Their own answer to this question has been heard. They hold themselves to be the ministers of a new religion more important than any the world has ever seen, a religion not only destined to supersede all others and bring final peace and satisfaction to humanity while in the flesh, but which answers better than any other the ingrained human aversion to extinction, and which vouchsafes a livelier picture than any other religion of the assumed existence beyond the grave. With such a conception of their high mission, these men cannot do otherwise than go out into the world and preach their gospel. Such an act is merely reflex to the circumstances which have led up to it.

There are certain consequences, however, of which we are bound to take account. Sir Arthur and Sir Oliver may be honest and devout, but the school of spiritism is broad and shelters many less luminous characters. The traffic of the ghost monger is notorious and baneful, and the encouragement which these shady characters receive from the campaign of the leaders of the psychical movement cannot but be lamented.

The point has been raised that this new religious system gives comfort to the bereaved at the time of greatest need. The leaders expressly bring forward this as the supreme object of their work. How far this attitude is justified may be open to serious question. There is little doubt that the bereaved parent concentrating emotionally on the memory of the dead child may eventually come into a mental state in which he believes himself in relationship with that child or in which he may even catch a vision or hear his voice. These abnormal states are familiar in mental medicine, and while by cultivating them a certain amount of satisfaction may be gained, it is legitimate to ask whether this is the wholesome and most suitable method of dealing with states of bereavement and sorrow. It may be that certain otherwise stable minds may indulge in these operations, derive a degree of comfort and suffer no serious injury ; for others, however, the procedure is distinctly unwholesome, if not dangerous, and to encourage it is to take risks unwarranted by any established facts. 